\title{
PEGylation of native disulfide bonds in proteins
}

\author{
Steve Brocchini ${ }^{1}$, Sibu Balan ${ }^{1}$, Antony Godwin ${ }^{1}$, Ji-Won Choi $^{3}$, Mire Zloh ${ }^{2}$ \& Sunil Shaunak ${ }^{3}$ \\ ${ }^{1}$ Department of Pharmaceutics, ${ }^{2}$ Department of Pharmaceutical and Biological Chemistry, The School of Pharmacy, University of London, 29/39 Brunswick Square, \\ London WC1N 1AX, UK. ${ }^{3}$ Faculty of Medicine, Imperial College London, Hammersmith Hospital, Ducane Road, London W12 0NN, UK. Correspondence should \\ be addressed to S.B. (steve.brocchini@pharmacy.ac.uk) or S.S. (s.shaunak@imperial.ac.uk).
}

Published online 14 December 2006; doi:10.1038/nprot.2006.346

PEGylation has turned proteins into important new biopharmaceuticals. The fundamental problems with the existing approaches to PEGylation are inefficient conjugation and the formation of heterogeneous mixtures. This is because poly(ethylene glycol) (PEG) is usually conjugated to nucleophilic amine residues. Our PEGylation protocol solves these problems by exploiting the chemical reactivity of both of the sulfur atoms in the disulfide bond of many biologically relevant proteins. An accessible disulfide bond is mildly reduced to liberate the two cysteine sulfur atoms without disturbing the protein's tertiary structure. Site-specific PEGylation is achieved with a bis-thiol alkylating PEG reagent that sequentially undergoes conjugation to form a three-carbon bridge. The two sulfur atoms are re-linked with PEG selectively conjugated to the bridge. PEGylation of a protein can be completed in $24 \mathrm{~h}$ and purification of the PEG-protein conjugate in another $3 \mathrm{~h}$. We have successfully applied this approach to PEGylation of cytokines, enzymes, antibody fragments and peptides, without destroying their tertiary structure or abolishing their biological activity.

\section{INTRODUCTION}

The therapeutic success of covalently conjugating PEG to proteins (PEGylation) is increasing the clinical use of biopharmaceuticals. Originally designed to improve pharmacokinetic profiles, PEGylation has been found to increase a protein's half-life in the vascular circulation and to reduce the dose of protein required for treatment. In addition, antibodies to PEG have not been observed during the clinical use of several PEG-protein conjugates. Recent clinical studies have also suggested new and unexpected therapeutic benefits for protein-based medicines ${ }^{1-3}$. For example, the combination of PEGylated $\alpha-2$ interferon and ribavirin eradicates hepatitis $\mathrm{C}$ virus in more than $50 \%$ of treated patients. This has led to several PEG-protein conjugates being approved for therapeutic use by the regulatory authorities ${ }^{4}$.

\section{Existing PEGylation technologies}

A major limitation with the existing PEGylated proteins is their heterogeneous nature. This is because PEG is conjugated at many different nucleophilic amine residues in the protein ${ }^{4-6}$. The relative proportion of each of these positional PEG-protein isomers depends on (i) terminal chemical functionality, (ii) molecular weight (MWt), (iii) morphology of PEG and (iv) the specific reaction conditions used for conjugation ${ }^{7}$. These problems make a systematic definition of structure-property correlations during a protein's preclinical development impossible.

Not only do small variations in the conjugation reaction conditions lead to a variable mixture of PEG-protein conjugates, but also a large stoichiometric excess of the PEG reagent is required ${ }^{8}$. Nonselective conjugation and the presence of excess PEG means that tedious purification processes are required to isolate the PEGprotein conjugate. The low efficiency of the conjugation reaction is a major impediment to the widespread use of protein-based medicines as cost-affordable drugs for global use ${ }^{9}$.

Our approach to protein PEGylation is able to address the fundamental issues of site-specific conjugation and high-efficiency conjugation. There are many conjugation strategies and many PEG-based reagents that have been developed to address the central issue of site-specific PEGylation ${ }^{10-13}$. Based on their selective chemical reactivity, thiol reactive PEG reagents offer the best opportunity for efficient and site-specific PEGylation. However, to use a thiol reactive PEG reagent, it is necessary to recombinantly engineer a new and free cysteine into the protein ${ }^{14}$ because most proteins do not have a free cysteine ${ }^{15,16}$. Engineering a single cysteine into a protein so that it is also accessible for the conjugation of PEG is technically demanding and expensive. A free unpaired cysteine reduces protein yield during refolding ${ }^{17}$, and may cause disulfide scrambling and may lead to aggregation of the protein $^{18}$.

Native disulfide bonds in extracellular proteins

Our starting point was naturally occurring proteins of biological importance with a MWt range of $10-50 \mathrm{kDa}$ and whose mode of action is via extracellular cell surface receptors. Typically, extracellular proteins have an even number of cysteines that pair up to form disulfide bonds. The complex functions of these disulfides can be considered in the simple terms of their relative contribution to a protein's structure, function and stability ${ }^{19,20}$. The disulfide bonds in a protein's hydrophobic interior are responsible for its structure and function, whereas disulfide bonds in close proximity to its surface are responsible for its stability ${ }^{20}$. Our search of protein databases suggests that most biologically relevant proteins have at least one disulfide bond that is close to the surface and that can also be chemically modified without resulting in a loss of either structure or function.

\section{Disulfide site-specific PEGylation}

Our methodological approach exploits the chemical reactivity of both of the sulfur atoms in a disulfide bond. We have found that the mild reduction of an accessible native disulfide to liberate its two sulfur atoms while retaining the protein's tertiary structure can be followed by site-specific PEGylation with a bis-thiol alkylating reagent (Fig. 1). Our approach enables the covalent re-bridging of the two thiols that are derived from the original disulfide bond $^{21-23}$ with a three-carbon methylene bridge to which PEG has been covalently attached.

It is important to preserve a protein's tertiary structure after the gentle reduction of an accessible disulfide to (i) keep the free thiols 
close to each other, (ii) minimize any potential for the irreversible denaturation and aggregation of the protein, and (iii) prevent disulfide scrambling reactions if more than one disulfide is reduced. Any protein that does not undergo conjugation with PEG can have its disulfides reoxidized

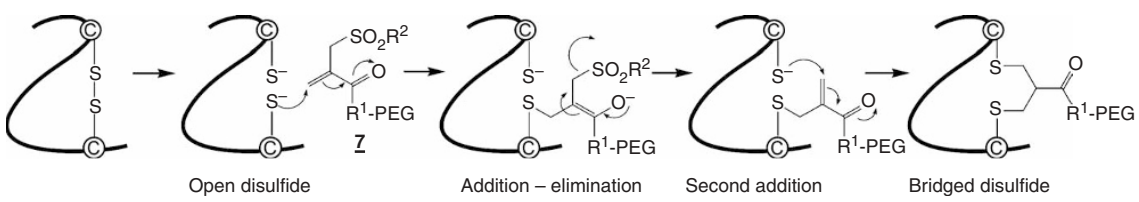
and can be re-used for another PEGylation reaction. As the native protein is the most expensive molecule, this can have a major impact on the cost of the PEGylated protein.

\section{Thiol-specific bis-alkylation}

The conjugating moiety of our PEG reagent 7 (Fig. 2) is a thiolspecific bis-alkylating group that comprises an electron-withdrawing group (e.g., carbonyl group), an $\alpha, \beta$-unsaturated double bond and a $\beta^{\prime}$ sulfonyl group that is susceptible to elimination. This juxtaposition of chemical functionality allows for a sequence of interactive and sequential addition-elimination reactions (Fig. 1). Competitive intermolecular alkylation reactions are minimized because all of the conjugation reactions occur in water and with a protein whose tertiary structure is maintained. We have prepared the PEG bis-sulfone reagent 6 using linear PEG's from 5,000 to $30,000 \mathrm{~g} \mathrm{~mol}^{-1}$ with little observed difference in conjugation efficiency. The PEG bis-sulfone reagent $\mathbf{6}$ can be used for conjugations that are conducted at neutral or slightly basic $\mathrm{pH}$ values where elimination of one of the $\beta$-sulfonyl groups leads to the generation of the PEG reagent 7 in situ. We have found that some peptides and proteins are more soluble when the reduction of the disulfide is conducted in slightly acidic conditions, for example, reduction of somatostatin ${ }^{23}$ at $\mathrm{pH} 6.2$ followed by conjugation with the PEG reagent 7.

The PEG mono-sulfone 7 is fundamentally different from the dithiol reactive PEGylation reagents that have been described. Such reagents have two separate thiol reactive functional groups (e.g., two maleimides ${ }^{24}$ ) that are chemically independent of each other. In addition, the distance between the two thiol reactive groups on these PEGylation reagents is much greater than the distance across the three-carbons of our PEG reagent 7 . Consequently, these difunctional reagents are incapable of undergoing sequential addition-elimination reactions, and there is little chance of re-bridging native disulfides and maintaining a protein's structure as described for our PEG mono-sulfone 7.

\section{Protein structure and modeling studies}

Several protein databases should be searched (Protein Data Bank, PDB-http://www.pdb.org) for the experimentally determined structure of the protein. In the absence of an experimentally based structure, it is possible to search databases of theoretically modeled structures, that is, Protein Model Database and SwissModel repository, http://a.caspur.it/PMDB and http:// swissmodel.expasy.org/repository. These may not provide an accurate structure but they will provide an insight into the protein's topology. The aim of these studies should be to identify the (i) accessible disulfides that contribute to stability, (ii) disulfides in the hydrophobic interior that contribute to structure and function, (iii) position of an accessible disulfide bond relative to the protein's receptor/substrate binding site(s) and (iv) effect on the protein's overall conformation of inserting a three-carbon bridge into a native disulfide bond. The protein's structure should be
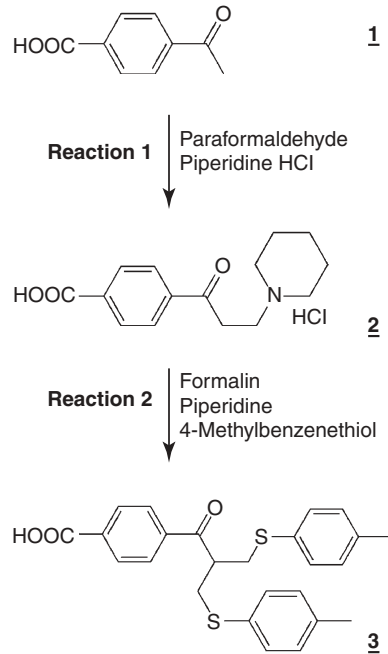

Reaction $3 \downarrow$ Oxone
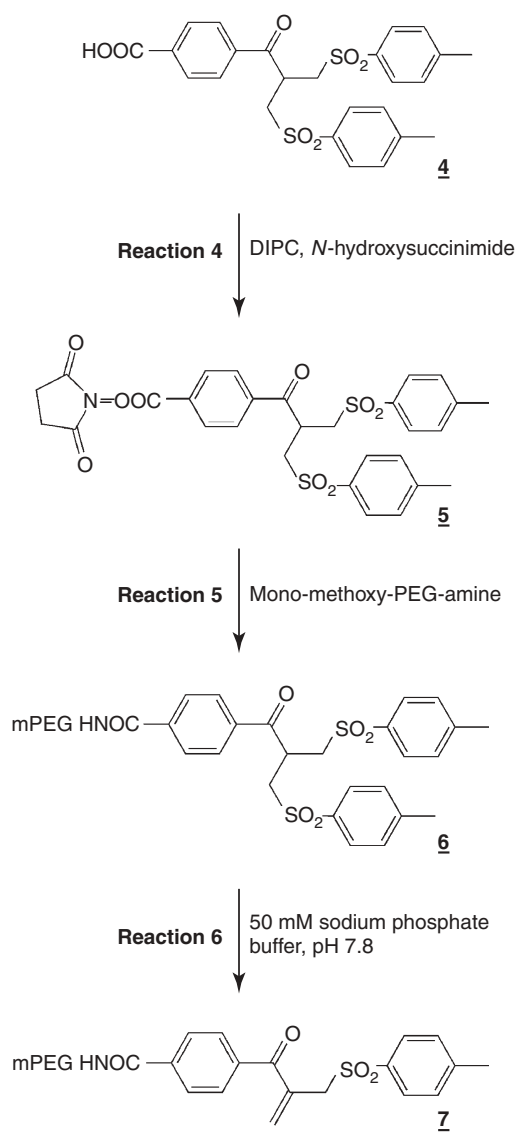

Figure 2 | Synthesis of PEG mono-sulfone 7. Typically, it was generated in situ from the PEG bis-sulfone 6 during the conjugation of the protein. 
checked for the correct numbering and completeness of the sequence. For example, the X-ray crystallographic structure of leptin (PDB entry 1AX8) did not include the flexible parts of the protein. As a result, we had to model this using a combination of homology modeling and molecular dynamics simulations.

There are more than 30,000 protein structures that contain cysteines in the PDB alone. As the disulfide bond may not be shown in the PDB file, the structure should be tested to determine whether any disulfides are present. This is possible with software (Disulfide by Design) that can locate pairs of cysteines that are in close proximity and which satisfy the geometric constraints on the sulfur atoms in a disulfide bond ${ }^{25}$. To locate the disulfides on a protein's surface, it is possible to calculate the solvent-accessible surface area using the web service GETAREA ${ }^{26}$ or MolMol software ${ }^{27}$. The results obtained should be confirmed by visual inspection using a molecular graphics package as shown in Figure 3. It is important to remember that these graphics provide a static picture only; a protein and its side chains are constantly in motion, with partially hidden sulfur atoms being regularly exposed to the solvent.

Detailed information about the surface conformation of the protein that interacts with its receptor/ligand has to come from the protein's crystal structure, from protein-receptor/ligand complexes or from biological data if these complexes have not been crystallized. Molecular modeling studies can then be undertaken using the integrated molecular modeling packages Maestro v6.5

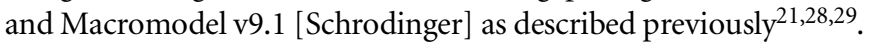
Their aim is to determine the effect of inserting a single threecarbon bridge into each of the accessible disulfides of a protein. For modeling studies, we recommend that, in the first instance, only one disulfide in a monomeric protein is modified. In the case of multimeric proteins, our studies suggest that a single PEG can be attached to each of the monomers that make up the protein without disrupting its structure or biological function ${ }^{22}$. For example, $\mathrm{L}$-asparaginase is active as a tetramer. Each monomeric b

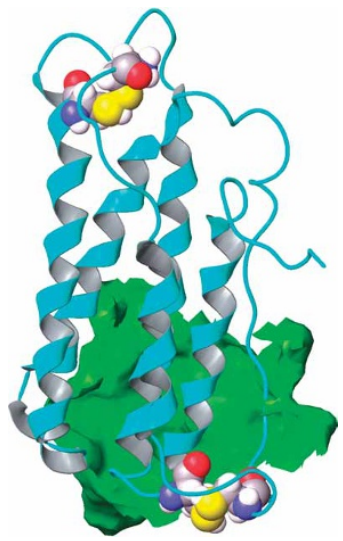

C

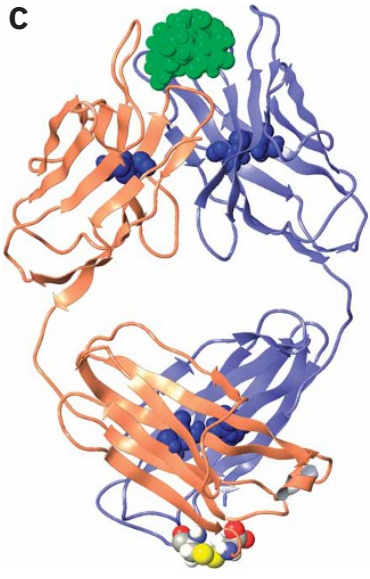

Figure 3 | Molecular graphic representation of the experimentally determined structures of three therapeutic proteins. (a) Leptin (PDB entry 1AX8); (b) IFN- $\alpha 2$ (PDB entry 1ITF) and (c) an antibody fragment that binds to a trinucleotide ligand (PDB entry $1 \mathrm{CBV}$ ). Protein backbones are shown as ribbons protein that interacts with its receptor is shown in green for leptin and IFN. For the Fab, the trinucleotide ligand is shown in green in a CPK representation.

it has one disulfide, which can be PEGylated in near quantitative yield with 1.3 equivalents of the PEG mono-sulfone reagent 7 (ref. 23). For proteins with more than one disulfide bond that can be easily reduced (e.g., interferon (IFN)), we conduct the PEGylation with one equivalent of the PEG bis-sulfone reagent $\mathbf{6}$ after reducing both disulfides. This results in a three-carbon disulfide singlebridged PEG-IFN with PEG conjugated to either Cys1-Cys98 or Cys29-Cys138 with only a small amount of three-carbon disulfide double-bridged PEG-IFN formed. If the three-carbon disulfide double-bridged PEG-IFN is required, it can be made using two equivalents of the PEG bis-sulfone 6 . In the case of a protein with multiple disulfides (e.g., an anti-CD4 antibody fragment), we have found that it is possible to reduce the most accessible interchain disulfide without affecting the less accessible intrachain disulfides. As a result, only a three-carbon disulfide single bridge was inserted into the antibody fragment. These observations suggest that when proteins have multiple disulfides with varying degrees of accessibility for reduction, only the accessible disulfide that has been reduced will be PEGylated ${ }^{22,23}$.

\section{MATERIALS}

\section{REAGENTS}

-1,3-Diisopropylcarbodiimide (DIPC; Sigma-Aldrich, cat. no. D125407)

I CAUTION Very toxic.

-Dithiothreitol (DTT; Sigma-Aldrich, cat. no. 43819) ! CAUTION Harmful.

- Ethylenediaminetetraacetic acid disodium salt dihydrate (EDTA; Sigma-

Aldrich-Fluka, cat. no. 03682)

• L-Glutathione, oxidized (GSSG; Sigma-Aldrich, cat. no. G4376) ! CAUTION

Irritant.

- L-Glutathione, reduced (GSH; Sigma-Aldrich, cat. no. G4251)

- N-Hydroxysuccinimide (Sigma-Aldrich, cat. no. 130672)

- Iodoacetamide (Sigma-Aldrich, cat. no. I1149) ! CAUTION Toxic.

- Magnesium sulfate, anhydrous

-4-Methylbenzenethiol (Sigma-Aldrich, cat. no. T28525) ! CAUTION Corrosive.

- $O$-(2-aminoethyl)- $O^{\prime}$-methylpolyethylene glycol, 5,000 $\mathrm{g} \mathrm{mol}^{-1}$

(Sigma-Aldrich, cat. no. 92192)
- O-(2-aminoethyl)- $O^{\prime}$-methylpolyethylene glycol, 10,000 or 20,000 $\mathrm{g} \mathrm{mol}^{-1}$

(NOF Corporation)

- Oxone (Sigma-Aldrich, cat. no. 228036) ! CAUTION Oxidizing and corrosive.

- Paraacetylbenzoic acid 1 (Sigma-Aldrich, cat. no. 177458)

- Paraformaldehyde (AlfaAesar, cat. no. A11313) ! CAUTION Harmful.

- Piperidine hydrochloride (AlfaAesar, cat. no. A13243) ! CAUTION Toxic.

- Sodium chloride

- Sodium dihydrogen orthophosphate dihydrate $\left(\mathrm{Na}_{2} \mathrm{H}_{2} \mathrm{PO}_{4} \cdot 2 \mathrm{H}_{2} \mathrm{O}\right.$, Fisher

Scientific UK, cat. no. S/3760/53)

- Silica gel 100 C18-reversed phase for column chromatography, fully

end-capped (Sigma-Aldrich-Fluka, cat. no. 60754) ! CAUTION Harmful.

- Acetone ! CAUTION Highly flammable.

-Acetonitrile, HPLC grade (Fisher Scientific, cat. no. A/0626/17) ! CAUTION

Highly flammable.

- Chloroform ! CAUTION Toxic. 
- Deionized water

- Dichloromethane, anhydrous (DCM; Sigma-Aldrich, cat. no. 270997) ! CAUTION Harmful.

-Ethanol, absolute! CAUTION Highly flammable.

- Formaldehyde, 37\% (wt/vol) aqueous solution ! CAUTION Toxic.

- Glacial acetic acid ! CAUTION Corrosive.

-Hydrochloric acid (38\% aqueous solution (w/wt); concentrated $\mathrm{HCl}$ )

! CAUTION Corrosive.

- Methanol ! CAUTION Highly flammable.

- Piperidine (Sigma-Aldrich, cat. no. 411027) ! CAUTION Highly flammable and toxic.

- Sodium hydroxide, 1 M standard solution (Sigma-Aldrich, cat. no. 319511)

- Toluene, anhydrous (Sigma-Aldrich, cat. no. 244511) ! CAUTION Highly

flammable.

- $50 \mathrm{mM}$ sodium phosphate buffer, $\mathrm{pH} 7.8$, containing $10 \mathrm{mM}$ EDTA

prepared using sodium dihydrogen orthophosphate dihydrate

- $20 \mathrm{mM}$ sodium acetate buffer, $\mathrm{pH} 4.0$, prepared using glacial acetic acid and

$1 \mathrm{M} \mathrm{NaOH}$

- $20 \mathrm{mM}$ sodium acetate buffer, $\mathrm{pH} 4.0$, containing $1 \mathrm{M} \mathrm{NaCl}$

. 50 mM GSH: $50 \mathrm{mM}$ GSSG solution prepared in $1 \mathrm{ml}$ of $20 \mathrm{mM}$ sodium

acetate buffer, $\mathrm{pH} 4.0$

EQUIPMENT

- Argon (BOC pureshield argon, EEC no. 2311470)

- Condenser, 24/40M

- Corning tube, $15 \mathrm{ml}$

- Disposable plastic syringes $(5 \mathrm{ml})$ and needles

- Dry ice (BOC)

- Eppendorf tube, $1.5 \mathrm{ml}$

-Eppendorf tube, $2 \mathrm{ml}$

- Funnel Pyrex Buchner porosity 3 borosilicate glass with sintered glass

disc 30-mm disc diameter, $35 \mathrm{ml}$ (Fisher Scientific UK, cat. no.

FPJ-400-050S)
- Funnel Pyrex Buchner porosity 3 borosilicate glass with sintered glass disc

40-mm disc diameter, $80 \mathrm{ml}$ (Fisher Scientific UK, cat. no. FPJ-400-130U)

- Glass pipette, $1 \mathrm{ml}$ graduated

- HiLoad 16/60 Superdex 200 prep grade column (GE Healthcare,

cat. no. 17-1069-01)

- HiTrap SP FF, 1 ml column (GE Healthcare, cat. no. 17-5054-01)

- Hot air gun (Bosch, Model PHG-500-2)

- Hot plate, temperature controlled

- HPLC system with UV detector

- Magnetic stir bar

- Measuring flask, $100 \mathrm{ml}$

- Non-absorbent cotton wool filter

- Paraffin oil bath

-PD-10 column (GE Healthcare, cat. no. 17-0851-01)

- Peristaltic pump

- Plastic disposable syringes and needles

- Reversed-phase C-18 silica gel packed \#3 Pyrex sintered glass funnel

- Rotary evaporator (Buchi)

- Round-bottom flasks: $100 \mathrm{ml}, 250 \mathrm{ml}$

- Rubber balloons

- Rubber septum for $50 \mathrm{ml}$ schlenk-type flask 14/20

-Schlenk-type solvent storage flask $(50 \mathrm{ml})$ with glass stopcock on the side arm 14/20F (Sigma-Aldrich, cat. no. Z173061)

- Separating extraction funnel, $500 \mathrm{ml}$

- Vacuum flask, $250 \mathrm{ml}$

-Vacuum oven

-Vacuum pump (Edwards, model E-lab-2) fitted with a vapor trap EQUIPMENT SETUP

HPLC setup Equilibrate the HiLoad superdex 200 prep grade column (GE Healthcare, cat. no. 17-1069-01) with at least two column volumes $(240 \mathrm{ml})$ of the pre-filtered buffer at a flow rate of $1 \mathrm{ml} \mathrm{min}^{-1}$. Turn on the UV detector and set the wavelength to $280 \mathrm{~nm}$.

\section{PROCEDURE}

Preparation of the PEGylation agent. Reaction 1, synthesis of carboxylic acid Mannich salt 2 (1-[3-(4-carboxy-phenyl)-3-oxo-propyl]-piperidinium $\mathrm{HCl}$ )

1) To a dry $250 \mathrm{ml}, 24 / 40$ standard tapered, single-neck round-bottom flask containing a magnetic stir bar, add absolute ethanol (30 ml), p-acetylbenzoic acid $1(5.0 \mathrm{~g}, 30.45 \mathrm{mmol}, 1$ equivalent), piperidine $\mathrm{HCl}(3.7 \mathrm{~g}, 30.45 \mathrm{mmol}, 1$ equivalent) and paraformaldehyde $(2.74 \mathrm{~g}, 91.35 \mathrm{mmol}, 3$ equivalents). To this solution, add concentrated $\mathrm{HCl}(0.3 \mathrm{ml})$ using a glass pipette.

2| Clamp the reaction flask to a retort stand in a fume hood. Fix a condenser to the flask and turn on the water to flow through the condenser.

3| Heat the reaction mixture to $105^{\circ} \mathrm{C}$ and allow it to stir at gentle reflux for $10 \mathrm{~h}$. Typically, this is accomplished with a heater-magnetic stirrer placed on a labjack under the flask. On the stirrer is placed paraffin oil $(300 \mathrm{ml})$ in a PYREX crystallization dish $(500 \mathrm{ml})$. The labjack is adjusted to bring the oil into contact with the reaction flask to cover the volume of liquid inside the reaction flask.

4 After $4 \mathrm{~h}$ reflux, lower the labjack to remove the reaction flask from the hot oil. Once the solution has stopped boiling, lift the condenser from the reaction flask and, using a powder funnel, carefully add paraformaldehyde $(2.74 \mathrm{~g}, 91.35 \mathrm{mmol}$, 3 equivalents). Reconnect the condenser to the reaction flask and adjust the labjack to again heat the reaction mixture to reflux.

5| After a further $6 \mathrm{~h}$ of reflux, turn off the heat source and allow the reaction mixture to cool to ambient temperature. Typically, a precipitate is seen in the flask on cooling.

6| Add acetone $(50 \mathrm{ml})$ to the reaction mixture and gently agitate the flask to mix the solution.

7| Filter the suspension using a \#3 Pyrex sintered glass funnel connected to vacuum via a vacuum flask and discard the filtrate.

PAUSE POINT Dry the white solid salt 2 obtained overnight in a vacuum oven.

\section{Preparation of the PEGylation agent. Reaction 2, synthesis of carboxylic acid bis-sulfide 3}

8| To a dry $100 \mathrm{ml}, 24 / 40$ standard tapered, single-neck round-bottom flask containing a magnetic stir bar, add absolute ethanol (12 ml), methanol $(8 \mathrm{ml})$, salt $2(3.5 \mathrm{~g}, 11.7 \mathrm{mmol}, 1$ equivalent), 4-methylbenzenethiol $(2.91 \mathrm{~g}, 23.48 \mathrm{mmol}$, 2 equivalents).

! CAUTION Owing to the strong smell of thiol, handle the 4-methylbenzenethiol carefully in a fume hood. To the reaction solution, add sequentially piperidine $(0.5 \mathrm{ml})$ and $37 \%(\mathrm{wt} / \mathrm{vol})$ aqueous formaldehyde $(3.5 \mathrm{ml})$ by pipette. 
9| Clamp the reaction flask to a retort stand in a fume hood. Fix a condenser to the flask and turn on the water to flow through the condenser.

! CAUTION Ensure that the water flow is not too high. Heat $\left(105^{\circ} \mathrm{C}\right)$ and stir the reaction mixture to a gentle reflux as in Reaction 1 (Step 3). Allow the reaction to proceed for $1 \mathrm{~h}$ at reflux.

10| After the $1 \mathrm{~h}$ reflux period, lower the labjack to remove the heat from the reaction flask. While the reaction solution is still being stirred, carefully add $37 \%$ (wt/vol) aqueous formaldehyde $(3.5 \mathrm{ml})$ by pipette through the top of the condenser. Raise the labjack and heat the stirred reaction mixture to reflux for a further $3 \mathrm{~h}$.

11 Allow the reaction mixture to cool to room temperature and fix the reaction flask to a rotary evaporator. Then evaporate the volatile solvents at reduced pressure while maintaining a temperature of $40{ }^{\circ} \mathrm{C}$ on the reaction flask. Remove the flask from the rotary evaporator and add methanol $(\approx 10 \mathrm{ml}$ ) to the creamy white residue.

12| Gently heat this solution in a fume hood to dissolve the crude product. Then allow the solution to cool to room temperature. Typically, a small amount of solid may form during this time.

- PAUSE POINT Stopper the mouth of the reaction flask and store it in a refrigerator $\left(4^{\circ} \mathrm{C}\right)$ overnight.

13| Filter the reaction mixture with a clean \#3 sintered glass funnel that is connected to vacuum via a vacuum flask. Collect the pale yellow solid carboxylic bis-sulfide 3 .

PAUSE POINT Allow the solid to dry overnight in vacuum at room temperature.

\section{Preparation of the PEGylation agent. Reaction 3, synthesis of carboxylic acid bis-sulfone 4}

14| Prepare a 1:1 methanol-deionized water solution (100 ml) and add it to a $500 \mathrm{ml}, 24 / 40$ standard tapered, single-neck round-bottom flask containing a magnetic stir bar. Clamp the flask to a retort stand placing a magnetic stirrer on the labjack underneath. To this solution, add carboxylic acid bis-sulfide $3(3.0 \mathrm{~g}, 6.87 \mathrm{mmol}, 1$ equivalent) and OXONE (25.34 g,

$41.22 \mathrm{mmol}, 4$ equivalents).

PAUSE POINT Allow the reaction to stir at ambient temperature for $24 \mathrm{~h}$.

15 Pour the mixture into a $500 \mathrm{ml}$ separatory funnel and extract twice with chloroform ( $50 \mathrm{ml}$ for each extraction). Add more water $(\approx 100 \mathrm{~mol})$ to dissolve all the inorganic solids and extract once more with chloroform $(100 \mathrm{ml})$.

! CAUTION Chloroform is toxic; so handle it carefully in a fume hood.

16| Combine the chloroform extracts in the separatory funnel and add brine solution $(100 \mathrm{ml})$. Then carefully separate the organic chloroform layer into a $500 \mathrm{ml}$ conical flask. Add magnesium sulfate $(\sim 5-10 \mathrm{~g})$ to this solution and swirl gently. After $5 \mathrm{~min}$, filter the solution by gravity using flutted filter paper placed in a glass funnel.

17| Pour the clear chloroform solution into a $500 \mathrm{ml}$ single-neck flask and evaporate the chloroform at reduced pressure by rotary evaporation while maintaining a temperature of $40{ }^{\circ} \mathrm{C}$ in the flask containing the chloroform solution.

18| As the evaporation of chloroform nears completion, the crude carboxylic acid bis-sulfone 4 will appear as white foam that has bubbled up from the inside surface of the flask.

19| Once the chloroform has evaporated from the product, remove the flask from the rotary evaporator and scrape off the white product. Transfer the solid to a tared wide-mouth jar.

20| With the cap loosely placed onto the jar, the carboxylic acid bis-sulfone 4 is dried overnight in a vacuum oven at reduced pressure and ambient temperature to constant weight.

\section{Preparation of the PEGylation agent. Reaction 4, synthesis of active ester bis-sulfone 5}

21| To a clean and dry $50 \mathrm{ml}$ Schlenk-type storage flask containing a magnetic stir bar, add carboxylic acid bis-sulfone 4 $(2.00 \mathrm{~g}, 4.0 \mathrm{mmol}, 1$ equivalent) and $\mathrm{N}$-hydroxysuccinimide $(0.483 \mathrm{~g}, 4.2 \mathrm{mmol}, 1.05$ equivalents).

22 Fit a rubber septum (for $14 / 20$ F flask mouth) to the standard tapered fitting of the flask and clamp the reaction flask to a retort stand with a labjack and magnetic stirrer. Connect the reaction flask to a high vacuum via its side arm and allow the solids to dry under reduced pressure for $30 \mathrm{~min}$.

23| Introduce argon through the septum using a rubber balloon filled with argon and fitted with a needle.

24| Add $5 \mathrm{ml}$ of anhydrous DCM into the flask through the rubber septum using a clean dry glass syringe fitted with a needle. Place an ice bath on the stirrer and raise the labjack to stir and cool the reaction mixture. Allow the flask to cool for $10 \mathrm{~min}$. 
PROTOCOL

25| Place the flask on a magnetic stirrer and turn on the magnetic stirrer allowing moderate stirring to occur.

26| Inject neat DIPC (657 $\mu \mathrm{l}, 4.2 \mathrm{mmol})$ dropwise into the flask through the rubber septum.

27| Allow the reaction to stir at ambient temperature for $1.5 \mathrm{~h}$.

28| Inject another $60 \mu \mathrm{LIPC}$ into the flask through the rubber septum after $1.5 \mathrm{~h}$.

29| After $3 \mathrm{~h}$ of reaction, remove the rubber septum and pass the reaction mixture through a non-absorbent cotton wool filter.

30| Dilute the homogeneous filtrate with DCM $(\approx 30 \mathrm{ml})$.

31 Add deionized water (15 ml). Mix the solutions in a separating extraction funnel and then isolate the organic DCM layer into a clean round-bottom flask. Repeat the extraction with deionized water $(15 \mathrm{ml})$ and collect the organic DCM layer into a clean round-bottom flask.

32 Add $1 \mathrm{~g}$ of anhydrous magnesium sulfate and swirl the solution gently for $5 \mathrm{~min}$. Filter the solution by gravity using fluted filter paper placed in a glass funnel.

33| Transfer the filtrate to a clean round-bottom flask and subject it to rotary solvent evaporation. Collect the white solid product obtained from the round-bottom flask.

PAUSE POINT Dry it overnight in a vacuum oven at ambient temperature.

\section{Preparation of the PEGylation agent. Reaction 5, synthesis of PEGylating reagent PEG bis-sulfone 6}

34 Remove the 0 -(2-aminoethyl)- $0^{\prime}$-methylpolyethylene glycol (e.g., 10,000 or $20,000 \mathrm{~g} \mathrm{~mol}^{-1}$ ) from its storage at $-20{ }^{\circ} \mathrm{C}$ and allow it to warm to room temperature.

35| To a dry $50 \mathrm{ml}$ Schlenk flask containing a magnetic stir bar, add $0.5 \mathrm{~g}$ of 0 -(2-aminoethyl)- $0^{\prime}$-methylpolyethylene glycol $\left(10,000 \mathrm{~g} \mathrm{~mol}^{-1}\right)(50 \mu \mathrm{mol}, 1$ equivalent$)$.

36| Fit the Schlenk flask with a rubber septum and then connect the stopper-opened side arm to the tube of the vapor trap of the vacuum pump. Ensure that the vapor trap is packed with dry ice. Turn on the vacuum pump and close the stopper of the side arm after 5 min. Turn off the vacuum pump.

37| Introduce argon through the rubber septum into the Schlenk flask using an argon-filled rubber balloon fitted with a needle and syringe.

38| Inject $5 \mathrm{ml}$ of anhydrous toluene through the rubber septum using a $5 \mathrm{ml}$ syringe.

39| Heat the bottom of the flask gently using a hot air gun until all the PEG dissolves in the toluene.

I CAUTION Do not overheat or allow the solution to boil; as the flask is sealed, the internal pressure can build up.

40| Allow the flask to cool down to room temperature and connect the stoppered side arm of the Schlenk flask to the heavy vacuum pump again and turn it on.

41| Turn on the stopper of the side arm very slowly allowing the vacuum to form within the flask. Bubbles will form during the vacuum evaporation process. Continue until all of the solvent has evaporated.

! CAUTION Gentle swirling of the flask by hand is necessary throughout this time to prevent spluttering of the solution when the heavy vacuum is on.

42 Allow the flask to remain under a heavy vacuum for at least $30 \mathrm{~min}$. Stopper the side arm and introduce the argon into the flask again.

43 Add $5 \mathrm{ml}$ of anhydrous DCM to the flask and place it on a magnetic stirrer. Cool the flask by placing it on an ice bath and turn on the magnetic stirrer. Allow moderate stirring to occur.

44| To a separate $25 \mathrm{ml}$ Schlenk flask, add $150 \mathrm{mg}$ of 4-[2,2-bis[(p-tolylsulfonyl)-methyl] acetyl]benzoic acid-NHS ester 5 ( $250 \mu \mathrm{mol}, 5$ equivalents). Fit the flask with a rubber septum and connect the stopper-opened side arm to the vacuum pump. Turn on the vacuum pump.

45| After $5 \mathrm{~min}$, stopper the side arm and turn off the vacuum pump. Introduce argon through the rubber septum into the Schlenk flask using an argon-filled rubber balloon fitted with a syringe and needle.

46 Inject $4 \mathrm{ml}$ of anhydrous DCM into the flask and allow the solids to dissolve completely by shaking the flask gently. Cool the flask in an ice bath for 5 min. 
47| Using a $5 \mathrm{ml}$ syringe fitted with a long needle, draw the solution completely through the rubber septum.

48| Inject the 4-[2,2-bis[(p-tolylsulfonyl)-methyl]acetyl]benzoic acid-NHS ester 5 solution dropwise into the Schlenk flask containing the PEG solution.

49| Allow the flask to cool down to room temperature.

PAUSE POINT Stir it for a further $48 \mathrm{~h}$ at $30^{\circ} \mathrm{C}$.

50| Evaporate the solvent containing the reaction mixture using a rotary evaporator without heating it to more than $40{ }^{\circ} \mathrm{C}$.

51| Measure $15 \mathrm{ml}$ of acetone and add it to the reaction flask. Gently warm the bottom of the flask until all of the solids dissolve and a clear solution is obtained. ! CAUTION Do not overheat the acetone to protect the product.

52| Place the flask in an ice bath and allow the solution to cool under stirring. The polymer starts to precipitate out slowly. Shake the flask occasionally. After $5 \mathrm{~min}$, filter the whole solution using a \#3 Pyrex Buchner funnel $(80 \mathrm{ml})$ with sintered glass disc (40-mm disc diameter) connected to a vacuum flask.

$\triangle$ CRITICAL STEP To maximize the yield of PEG, the filtration process should be carried out quickly and while the solution is still cold. The filter can be chilled before use. Repeat the acetone purification and precipitation procedure once more.

- PAUSE POINT Dry the sintered funnel containing the polymer overnight in a vacuum oven. As the PEG bis-sulfone 6 is stable at an acidic $\mathrm{pH}$, this solution can be stored under argon at $-20{ }^{\circ} \mathrm{C}$ for up to 3 months (Box 1 and Fig. 4).

\section{Conjugation of PEG bis-sulfone 6 to a protein}

53| To an Eppendorf tube, add the protein solution (1 ml) made up in $50 \mathrm{mM}$ sodium phosphate buffer, $\mathrm{pH} 7.8$, containing $10 \mathrm{mM}$ EDTA at a concentration of $0.5 \mathrm{mg} \mathrm{ml}^{-1}$. pH 7.8 allows the PEG bis-sulfone 6 to undergo an elimination reaction in situ and generate the PEG mono-sulfone 7. When an acidic pH (i.e., 5.5-6) is required for the PEGylation reaction, PEG mono-sulfone 7 should be used. The bis-thiol alkylation occurs efficiently even at a slightly acidic pH.

54| Add DTT (15.4 mg, $100 \mathrm{mM}$ final concentration) to the Eppendorf tube containing the protein solution. Close the tube and mix the contents by shaking the tube slowly.

? TROUBLESHOOTING

55| Keep the solution still for $30 \mathrm{~min}$ at ambient temperature.

56 Equilibrate a PD-10 column with $25 \mathrm{ml}$ of $50 \mathrm{mM}$ sodium phosphate buffer, pH 7.8, containing $10 \mathrm{mM}$ EDTA with the aid of a column extension reservoir.

\section{BOX 1 | REACTION 6. PREPARATION OF PEGYLATING REAGENT PEG MONO-SULFONE 7}

Most PEGylation reactions are conducted with the PEG bis-sulfone 6 at neutral or slightly basic pH values. The PEG mono-sulfone 7 is generated in situ in these reaction conditions (Fig. 4). If PEGylation is to be attempted at slightly acidic conditions, then the PEG mono-sulfone 7 can be used.

EQUIPMENT SETUP

A preparative grade reversed-phase $\mathrm{C}-18$ flash chromatographic setup is used for the isolation of the PEG mono-sulfone 7. The equipment setup involves packing $10 \mathrm{~g}$ of reversed phase $\mathrm{C}-18$ silica gel in a \#3 Pyrex Buchner funnel ( $35 \mathrm{ml}$ ) with sintered glass disc ( $30-\mathrm{mm}$ disc diameter). The reservoir above the packing should have a capacity of more than $25 \mathrm{ml}$. The C-18 flash chromatographic column is connected to a vacuum pump using a vacuum flask. The packing is first washed with acetonitrile to remove any impurities. For this, the reservoir is first loaded with $25 \mathrm{ml}$ of acetonitrile and the vacuum is then turned on to allow the solvent to pass through while leaving the packing dry. The packing is similarly washed twice with deionized water (25 $\mathrm{ml}$ each) to equilibrate the column.

1. To a $25 \mathrm{ml}$ round-bottom flask, add $0.2 \mathrm{~g}$ of PEG bis-sulfone 6 .

2. Add $10 \mathrm{ml}$ of $50 \mathrm{mM}$ sodium phosphate buffer, $\mathrm{pH} \mathrm{7.8,} \mathrm{to} \mathrm{the} \mathrm{flask} \mathrm{and} \mathrm{allow} \mathrm{the} \mathrm{solid} \mathrm{to} \mathrm{dissolve.}$

3. The solution formed is allowed to stand for $16 \mathrm{~h}$ at $25^{\circ} \mathrm{C}$.

4. The reaction mixture is then loaded onto the deionized water pre-equilibrated reversed-phase flash chromatographic column reservoir (SAMPLE LOAD).

5. The solution is allowed to pass through the C-18 packing by applying a vacuum.

6. The column packing is similarly washed twice with $25 \%$ (vol/vol) acetonitrile in water (25 ml each) (WASH).

7. The filtrate solution that is collected in the vacuum flask during the sample load and the two washes are discarded, and the vacuum flask cleaned.

8. The packing is then washed with $75 \%$ ( $\mathrm{vol} / \mathrm{vol}$ ) acetonitrile in water and the filtrate obtained ( $25 \mathrm{ml})$ is diluted with deionized water ( $75 \mathrm{ml}$ ) and frozen.

9. The frozen solution is then subjected to freeze drying to obtain the PEG mono-sulfone 7 product. Typically, 75-85\% PEG mono-sulfone 7 is obtained, with the remainder being the PEG bis-sulfone 6 . Analysis is by ${ }^{1} \mathrm{H}-\mathrm{NMR}$. 
57| Load the protein solution $(1 \mathrm{ml})$ onto the pre-equilibrated PD-10 column and collect the $1 \mathrm{ml}$ eluate as the load volume.

58| Add fresh buffer ( $2 \mathrm{ml}$ ) to the PD-10 column and collect the eluate separately.

59| Add further fresh buffer $(2.5 \mathrm{ml})$ to the PD-10 column while collecting the eluate in a $15-\mathrm{ml}$ corning tube.

$\triangle$ CRITICAL STEP Allow the protein solution to trickle down the sides of the tube. Typically, this fraction contains $96 \%$ of the protein in a reduced form with all of the DTT removed.

60| Dissolve PEG bis-sulfone 6 at a concentration of $10-15 \mathrm{mg} \mathrm{ml}^{-1}$ in $20 \mathrm{mM}$ sodium acetate buffer, $\mathrm{pH} 4.0$.
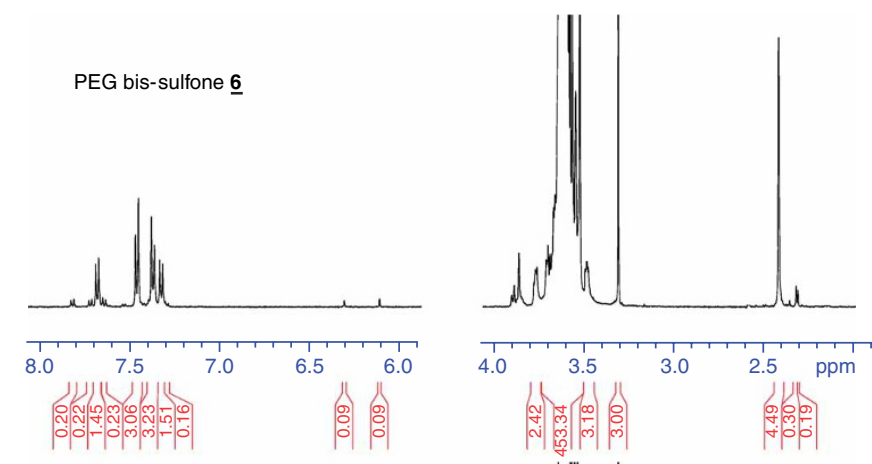

61| Add the PEG bis-sulfone 6 solution (1 equivalent if monoPEGylation is desired) to the reaction tube. Typically, the volume of the PEG solution is less than or equal to $50 \mu$. $\triangle$ CRITICAL STEP As with any reduced protein care must be taken to ensure the protein does not undergo denaturation.

- PAUSE POINT Allow the conjugation reaction to proceed by incubating the reaction mixture for at least $8 \mathrm{~h}$ (or overnight) at $4{ }^{\circ} \mathrm{C}$.

62 Add $50 \mu \mathrm{l}$ of $50 \mathrm{mM}$ glutathione reoxidizing solution to yield a concentration of $\approx 1 \mathrm{mM} \mathrm{GSH}: 1 \mathrm{mM}$ GSSG in $2.5 \mathrm{ml}$.

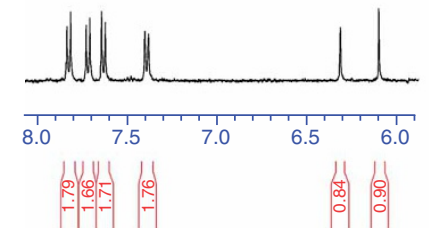

Figure $4 \mid{ }^{1} \mathrm{H}-\mathrm{NMR}$ spectra of PEG bis-sulfone 6 (top) and PEG mono-sulfone 7 (bottom) in $\mathrm{D}_{2} 0$.

Mix and store the reaction solution for a further $16 \mathrm{~h}$ at $4{ }^{\circ} \mathrm{C}$.

$\triangle$ CRITICAL STEP This step reoxidises any thiols back to their original disulfide bonds. This is one of many routine ways to oxidize thiols to disulfides ${ }^{31}$.

\section{Purification of PEG-protein conjugate}

63 Load the reaction solution $(2.5 \mathrm{ml})$ onto a PD-10 column that has been pre-equilibrated with $20 \mathrm{mM}$ sodium acetate buffer, $\mathrm{pH}$ 4.0.

64 Then, eluate the PD-10 column with $3.5 \mathrm{ml}$ of fresh $20 \mathrm{mM}$ sodium acetate buffer, $\mathrm{pH}$ 4.0, while collecting the eluate.

65 Then, draw this solution into a $5 \mathrm{ml}$ syringe with the help of a long needle.

66 Collect residues of any product that is left in the tube. To this, add $1.5 \mathrm{ml}$ of fresh $20 \mathrm{mM}$ sodium acetate buffer, $\mathrm{pH}$ 4.0. This solution is then pooled with the $3.5 \mathrm{ml}$ reaction solution from Step 68 .

67| Load the $5 \mathrm{ml}$ of solution manually into the ion exchange column (pre-equilibrated with $20 \mathrm{ml}$ of $20 \mathrm{mM}$ sodium acetate buffer, $\mathrm{pH} 4.0$, to remove contaminants) with the help of a syringe at a flow rate of $1 \mathrm{ml} \mathrm{min}{ }^{-1}$. Maintain this flow rate while injecting the protein solution into the column. In the case of IFN, the column used was a cation exchange column (HiTrap SP FF, GE Healthcare). However, the choice of ion exchange column depends entirely on the isoelectric point ( $\mathrm{p} I$ ) of the protein. As IFN has a $\mathrm{p} I$ of $\approx 6.0$, the cation exchange chromatography has to be used after exchanging the protein to $20 \mathrm{mM}$ sodium acetate buffer, $\mathrm{pH}$ 4.0. Anion exchange chromatography can also be used by exchanging the protein buffer to $\mathrm{pH} 8.0$ or above.

68| Wash the column with $2 \mathrm{ml}$ of $20 \mathrm{mM}$ sodium acetate buffer, $\mathrm{pH} 4.0$, at a flow rate of $2 \mathrm{ml} \mathrm{min}^{-1}$ with the help of a peristaltic pump.

69| Load a fresh syringe with $5 \mathrm{ml}$ of $20 \mathrm{mM}$ sodium acetate buffer, $\mathrm{pH} 4.0$, containing $1 \mathrm{M}$ sodium chloride and attach the syringe to the ion exchange column.

70| Inject the buffer in the syringe manually at a flow rate of $1 \mathrm{ml} \mathrm{min}-1$. Discard the initial $1 \mathrm{ml}$ eluate. Collect the next $2 \mathrm{ml}$ of the elution volume (which contains the protein and the conjugation mixture) in a $2 \mathrm{ml}$ Eppendorf tube and assay the protein content by micro-BCA assay (see below).

? TROUBLESHOOTING. 
71 Inject the ion exchange purified solution $(1.9 \mathrm{ml})$ into the SEC-HPLC (size exclusion chromatography-HPLC) for purification of the protein and the conjugation mixture.

$\triangle$ CRITICAL STEP The eluting characteristics of the PEG-protein conjugate will be dominated by the PEG for proteins with a small MWt. For example, unconjugated $10 \mathrm{kDa}$ PEG bis-sulfone 6 will eluate at approximately 78 min (peak maximum) in the conditions for SEC-HPLC described here. When conjugated to cytokines with MWts ranging from 16 to $19 \mathrm{kDa}$, the elution time is approximately $70 \mathrm{~min}$. Lower MWt proteins conjugated to $10 \mathrm{kDa}$ PEG would be expected to eluate in the range between 70 and $78 \mathrm{~min}$. In the case of the $20 \mathrm{kDa}$ PEG bis-sulfone 6, the unconjugated reagent eluates at about $64 \mathrm{~min}$. When conjugated to cytokines with MWts ranging from 16 to $19 \mathrm{kDa}$, the PEG-protein conjugate eluates at about 60 min. Smaller proteins conjugated to a $20 \mathrm{kDa}$ PEG would be expected to eluate in the range of 60-64 min.

? TROUBLESHOOTING

\section{Quantitation of the protein and the purified PEGylated protein}

72| The standard methods for quantitation of proteins are UV and the micro-BCA assay ${ }^{30}$. The latter has the advantage that a smaller amount of protein is required to perform the assay. A third method relies upon the use of antibodies (usually monoclonal), which are used in the context of a quantitative, commercial enzyme immunoassay. Very small amounts of proteins can be quantitated using this approach. Our experience suggests that micro-BCA can be reliably used to quantify the amount of protein that is covalently conjugated to PEG in the purified PEGylated protein, but that caution is required if an enzyme immunoassay is to be used. For some proteins, we have found a significant difference between the results obtained using an enzyme immunoassay when compared with those obtained using a micro-BCA assay.

\section{TIMING}

\section{Reaction 1. Synthesis of carboxylic acid Mannich salt 2}

Steps 1 and 2, 30 min; Steps 3 and 4, 10.5 h; Step 5, 30 min; Steps 6 and 7, 15 min; Step 8, 16 h.

Reaction 2. Synthesis of carboxylic acid bis-sulfide 3

Steps 1 and 2, 30 min; Steps 3-5, 4.5 h; Step 6, 15 min; Step 7, 30 min; Step 8, 16 h; Step 9, 10 min; Step 10, 16 h.

Reaction 3. Synthesis of carboxylic acid bis-sulfone 4

Step 1, 30 min; Step 2, 24 h; Steps 3-8, 1 h; Step 9, 16 h.

Reaction 4. Synthesis of active ester bis-sulfone 5

Step 1, 10 min; Steps 2-7, 45 min; Step 8, 1.5 h; Steps 9 and 10, 1.5 h; Steps 11-13, 45 min; Step 12, 30 min; Step 15, 16 h. Reaction 5. Preparation of PEG bis-sulfone 6

Steps 1-9, 30 min; Step 10, 30 min; Steps 11-16, 15 min; Step 17, 48 h; Steps 18-20, 15 min; Step 21, 24 h.

Reaction 6. Preparation of PEG mono-sulfone 7

Steps 1-2, 10 min; Steps 3 and 4, 16 h; Steps 5-9, 1 h; Step 10, 24 h.

Conjugation of PEG bis-sulfone 6 to a protein

Steps 1 and 2, $10 \mathrm{~min}$; Steps 3 and 4, $30 \mathrm{~min}$; Step 5, $15 \mathrm{~min}$; Steps 6-8, $10 \mathrm{~min}$; Step 9, $10 \mathrm{~min}$; Step 10, 5 min; Step 11, 8 h; Step 12, $16 \mathrm{~h}$.

Purification of PEG-protein conjugate

Steps 1-9, 15 min; Step 10, 2 h.

? TROUBLESHOOTING

Troubleshooting advice can be found in Table 1.

TABLE 1 | Troubleshooting table.

\begin{tabular}{|c|c|c|}
\hline Problem & Possible reasons & Solutions \\
\hline \multirow[t]{4}{*}{$\begin{array}{l}\text { Protein precipitates after its } \\
\text { reduction }\end{array}$} & Physical instability & $\begin{array}{l}\text { Avoid vigorous shaking of the reduced protein } \\
\text { solution }\end{array}$ \\
\hline & Thermal instability & $\begin{array}{l}\text { Use an adjuvant, e.g. an amino acid such as } \\
\text { L-arginine in the solution and reaction buffers }\end{array}$ \\
\hline & & Reduce the protein in cool and dry conditions \\
\hline & & $\begin{array}{l}\text { Do not expose the reduced protein solution to } \\
\text { heat or direct sunlight }\end{array}$ \\
\hline $\begin{array}{l}\text { Protein aggregates during the } \\
\text { conjugation reaction }\end{array}$ & Protein concentration is too high & $\begin{array}{l}\text { Reduce the concentration of protein in the } \\
\text { reaction }\end{array}$ \\
\hline PEGylation yield is low & $\begin{array}{l}\text { Contamination of water and reagents with oxidizing } \\
\text { agents and divalent cations }\end{array}$ & $\begin{array}{l}\text { Use the highest grade chemicals available and } \\
\text { purge all solutions with argon for } 30 \mathrm{~min}\end{array}$ \\
\hline
\end{tabular}


PROTOCOL

TABLE 1 | Troubleshooting table.

\begin{tabular}{|c|c|c|}
\hline Problem & Possible reasons & Solutions \\
\hline $\begin{array}{l}\text { On PAGE, the PEG is seen as several } \\
\text { bands when stained with barium } \\
\text { iodide }\end{array}$ & $\begin{array}{l}\text { Difunctional PEG precursors and high molecular } \\
\text { weight PEG are a common "impurity". PEG is also } \\
\text { polydispersed }\end{array}$ & $\begin{array}{l}\text { Multiple bands are also seen with high-grade, } \\
\text { commercial PEG reagents. These species of } \\
\text { PEG are much larger than the PEG of interest } \\
\text { (i.e., } 10-30 \mathrm{kDa} \text { ). They can be removed during } \\
\text { the ion-exchange purification procedures. } \\
\text { They do not interfere with the conjugation } \\
\text { of PEG to protein }\end{array}$ \\
\hline $\begin{array}{l}\text { HPLC retention times of the } \\
\text { PEGylated protein varies }\end{array}$ & $\begin{array}{l}\text { Variation in the properties of the SEC column being } \\
\text { used. These include small changes in the mobile } \\
\text { phase composition, flow rate and temperature }\end{array}$ & $\begin{array}{l}\text { Isolate each peak and then identify each species. } \\
\text { A good and quick method is PAGE of the reaction } \\
\text { solution and of each purified peak }\end{array}$ \\
\hline
\end{tabular}

\section{ANTICIPATED RESULTS}

Typical yields for IFN

Reaction 1: Synthesis of carboxylic acid Mannich salt 2

$4.1 \mathrm{~g}, 45 \%$

Reaction 2: Synthesis of carboxylic acid bis-sulfide 3

$3.6 \mathrm{~g}, 75 \%$

Reaction 3: Synthesis of carboxylic acid bis-sulfone 4

$3.0 \mathrm{~g}, 84 \%$

Reaction 4: Synthesis of active NHS ester 5

$1.89 \mathrm{~g}, 79 \%$

Reaction 5: Preparation of PEG bis-sulfone 6

$0.45 \mathrm{~g}, 81 \%$

Conjugation of PEG bis-sulfone 6 to IFN

Step 8, PD-10 separation- $0.480 \mathrm{mg}$ in $2.5 \mathrm{ml}, 96 \%$

Purification of PEG-IFN

Step 2, PD-10 buffer exchange-93\% (0.465 mg in $3.5 \mathrm{ml})$

Step 10, Ion exchange purification-74\% $(0.37 \mathrm{mg}$ in $2 \mathrm{ml})$

Size-exclusion chromatography of the PEG-IFN

Three-carbon disulfide single-bridged $10 \mathrm{kDa}$ PEG-IFN: $\approx 57 \%$

Three-carbon disulfide double-bridged 10 kDa PEG-IFN: $\approx 9 \%$

IFN: $\approx 32 \%$

Aggregated IFN: $\approx 2 \%$

\section{Analytical data}

Carboxylic acid Mannich salt 2: ${ }^{1} \mathrm{H}-\mathrm{NMR}\left(\mathrm{dmso}-\mathrm{d}_{6}\right): 1.5-1.8\left(2 \mathrm{H} \mathrm{CH}_{2} \mathrm{CH}_{2} \mathrm{CH}_{2} \mathrm{~N}\right.$ and $\left.4 \mathrm{H} \mathrm{CH}_{2} \mathrm{CH}_{2} \mathrm{CH}_{2} \mathrm{~N}\right), 3.23\left(\mathrm{~s}, 4 \mathrm{H} \mathrm{CH}_{2} \mathrm{CH}_{2} \mathrm{CH}_{2} \mathrm{~N}\right)$, $3.38\left(\mathrm{t}, 2 \mathrm{H}, \mathrm{NCH}_{2} \mathrm{CH}_{2} \mathrm{CO}\right), 3.69\left(\mathrm{t}, 2 \mathrm{H}, \mathrm{NCH}_{2} \mathrm{CH}_{2} \mathrm{CO}\right), 8.10(\mathrm{~m}, 4 \mathrm{H}$, aromatic $\mathrm{CH}), 10.3(\mathrm{Br}, 1 \mathrm{H}, \mathrm{COOH})$.

Carboxylic acid bis-sulfide 3: ${ }^{1} \mathrm{H}-\mathrm{NMR}\left(\mathrm{CDCl}_{3}\right): 2.38(\mathrm{~s}, 6 \mathrm{H}), 3.16-3.31(\mathrm{~m}, 4 \mathrm{H}), 3.85(\mathrm{q}, 1 \mathrm{H}), 7.15(\mathrm{~d}, 4 \mathrm{H}), 7.18(\mathrm{~d}, 4 \mathrm{H}), 7.64$ $(\mathrm{d}, 2 \mathrm{H}), 8.07$ (d, 2H); ${ }^{13} \mathrm{C}-\mathrm{NMR}\left(\mathrm{CDCl}_{3}\right): 200.50,137.24,131.55,131.15,130.17,129.86,128.29,45.88,36.41,21.10 ;$ TOF MS ES+: $[M+H]+: 437.1240$.

Carboxylic acid bis-sulfone 4: ${ }^{1} \mathrm{H}-\mathrm{NMR}\left(\mathrm{CDCl}_{3}\right): 2.49(\mathrm{~s}, 6 \mathrm{H}), 3.48-3.66(\mathrm{~m}, 4 \mathrm{H}), 4.40(\mathrm{q}, 1 \mathrm{H}), 7.37(\mathrm{~d}, 4 \mathrm{H}), 7.70-7.73(\mathrm{~m}, 6 \mathrm{H})$, $8.10(\mathrm{~d}, 2 \mathrm{H}) ;{ }^{13} \mathrm{C}-\mathrm{NMR}\left(\mathrm{CDCl}_{3}\right): 195.43,170.09,145.62,138.24,135.35,133.74,130.59,130.23,128.59,128.35 ;$ TOF MS ES+: $[\mathrm{M}+\mathrm{H}]+: 501.10 \mathrm{Da}$.

Bis-sulfone NHS ester 5: ${ }^{1} \mathrm{H}$ NMR: $\left(\mathrm{CDCl}_{3}, 400 \mathrm{MHz}\right) \delta 2.48\left(\mathrm{~s}, 6 \mathrm{H}, \mathrm{CH}_{3}\right), 2.94\left(\mathrm{~s}, 4 \mathrm{H}, \underline{\mathrm{CH}}_{2} \underline{\mathrm{C}}_{2}\right), 3.56\left(\mathrm{~A} 2 \mathrm{~B} 2 \mathrm{X}, 4 \mathrm{H}, \mathrm{CH}_{2} \mathrm{C}\right), 4.38$ (quintet, $1 \mathrm{H}, \mathrm{CH}, \mathrm{J}=6.3 \mathrm{MHz}), 7.37,7.70\left(\mathrm{AB} \mathrm{q}, \mathrm{SO}_{2} \mathrm{Ar}, 8 \mathrm{H}, \mathrm{J}=8.0\right.$ and $8.3 \mathrm{MHz}$, respectively), 7.76, 8.14 (AB q, $\mathrm{COAr}, 4 \mathrm{H}$, $J=8.6 \mathrm{MHz}) ;{ }^{13} \mathrm{C} \mathrm{NMR:}\left(\mathrm{CDCl}_{3}, 400 \mathrm{MHz}\right) \delta 195.29,168.92,160.95,145.63,139.11,135.29,130.92,130.24,129.59,128.73$, $128.28,55.67,35.89,25.70,21.70$; MALDI-TOF MS: $\mathrm{m} / z=620.3070[\mathrm{M}+\mathrm{Na}]^{+}$.

PEG bis-sulfone 6: ${ }^{1} \mathrm{H}$ NMR: $\left(\mathrm{CDCl}_{3}, 400 \mathrm{MHz}\right) \delta 2.49\left(\mathrm{~s}, 6 \mathrm{H}, \mathrm{CH}_{3} \mathrm{Ar}\right), 3.38\left(\mathrm{~s}, 3 \mathrm{H}, \mathrm{CH}_{3} \mathrm{OPEG}\right), 3.44-3.84\left(\mathrm{~m}, \mathrm{PEG}+4 \mathrm{H}, \mathrm{CH}_{2} \mathrm{SO}_{2}\right)$, 4.34 CHCO (qn, $1 \mathrm{H}, \mathrm{CHCO}), 7.36,7.69\left(\mathrm{AB} \mathrm{q}, \mathrm{SO}_{2} \mathrm{Ar}, 4 \mathrm{H}, \mathrm{J}=8.2\right.$ and $8.4 \mathrm{MHz}$, respectively), 7.64, 7.81 ( $\mathrm{AB} \mathrm{q}, \mathrm{COAr}, 4 \mathrm{H}, \mathrm{J}=$ 8.4 and 8.2 MHz, respectively); ${ }^{13} \mathrm{C} \mathrm{NMR:}\left(\mathrm{CDCl}_{3}, 500 \mathrm{MHz}\right) \delta 195.11,166.14,145.51,139.43,136.19,135.37,130.19,128.63$, $128.31,127.68,71.94,70.57,69.59,59.01,55.56,40.01,35.61,21.72$. 
PEG mono-sulfone 7: ${ }^{1} \mathrm{H}$ NMR: $\left(\mathrm{CDCl}_{3}\right.$, $400 \mathrm{MHz}) \delta 2.35\left(\mathrm{~s}, 3 \mathrm{H}, \mathrm{CH}_{3} \mathrm{Ar}\right), 3.31$ ( $\left.\mathrm{s}, 3 \mathrm{H}, \mathrm{CH}_{3} \mathrm{OPEG}\right), 3.39-3.76$ (m, PEG), $4.28\left(\mathrm{~s}, 2 \mathrm{H}, \mathrm{CH}_{2} \mathrm{SO}_{2}\right), 5.93,6.22(\mathrm{~s}, 2 \mathrm{H}$, $\left.\mathrm{CH}_{2}=\mathrm{C}\right), 7.26,7.64\left(\mathrm{AB} \mathrm{q}, \mathrm{SO}_{2} \mathrm{Ar}, 4 \mathrm{H}\right.$, $\mathrm{J}=8.3$ and $8.6 \mathrm{MHz}$, respectively), 7.72, 7.81 (AB q, COAr, 4H, J = 8.1 and $8.3 \mathrm{MHz}$, respectively).

\section{Techniques for characterization of the purified PEGylated protein}

(a) SDS-polyacrylamide gel electrophoresis (PAGE) (Fig. 5a), Silver staining and Western blotting (Fig. 5b) to confirm the identity of the PEGylated protein $^{22,23}$.

(b) MALDI-TOF spectrometry to confirm the PEGylated protein's mass and polydispersity of the $\mathrm{PEG}^{22,23}$. (c) Circular dichroism spectroscopy to confirm the $\alpha$-helical structure of the protein $^{22}$.

(d) Assays to confirm the biological activity of the protein 22,23 .

\section{Electrophoresis and staining for protein}

The results for a $10 \mathrm{kDa}$ PEG-leptin, a $20 \mathrm{kDa}$ three-carbon disulfide (single and double) bridged PEG-IFN and a 20 kDa PEG-anti-CD4 Fab are shown in Figure 5. a

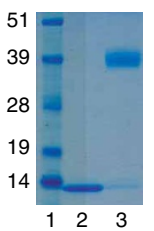

C

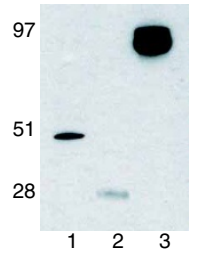

b

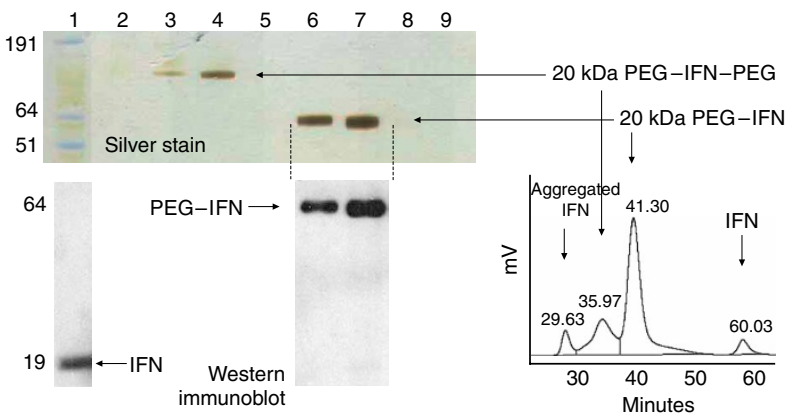

Figure 5 | (a) 10 kDa PEG-leptin. PAGE with a colloidal blue stain for protein. Lanes: (1) MWt markers in kDa; (2) leptin; (3) three-carbon disulfide single-bridged 10 kDa PEG-leptin. PEGylated proteins migrate more slowly on PAGE than would be expected for their molecular weight. As a guide, the PEGylated protein will migrate with an MWt that is twice the MWt of the PEG. (b) Purity of the isolated $20 \mathrm{kDa}$ three-carbon disulfide (single-bridged (i.e., PEG-IFN) and double-bridged (i.e., PEG-IFN-PEG)) PEGylatedIFN fractions on a 4-12\% bis-tris SDS-PAGE gel. Lanes stained with silver for protein: (1) MWt markers in KDa; (2) SEC-HPLC fractions 29-31 min; (3) 31-33 min; (4) 33-35 min; (5) 35-37 min; (6) 37-39 min; (7) 39-41 min; (8) 41-43 $\mathrm{min}$; (9) 43-45 min. Lanes 6 and 7 also show a Western blot of the threecarbon disulfide single-bridged PEG-IFN with an anti-IFN antibody. The PEG-IFN fractions are related to their SEC-HPLC chromatogram of the cationic-exchange-purified reaction mixture. The relative proportions of three-carbon disulfide single- and double-bridged PEG-IFN can be changed as described in Step 60 of PROCEDURE. (c) 20 kDa PEG-Fab. Western blot with an anti-Fab antibody. Lanes: (1) Fab; (2) reduced Fab; (3) three-carbon disulfide single-bridged $20 \mathrm{kDa}$ PEG-Fab.

ACKNOWLEDGMENTS We are grateful to the Wellcome Trust (068309) and BBSRCUK (BB/D003636/1) for funding.

COMPETING INTERESTS STATEMENT The authors declare competing financial interests (see the HTML version of this article for details).

Published online at http://www.natureprotocols.com/

Reprints and permissions information is available online at http://npg.nature.com/ reprintsandpermissions

1. Fried, M.W. et al. PEGinterferon alfa-2a plus ribavirin for chronic hepatitis $\mathrm{C}$ virus infection. N. Engl. J. Med. 347, 975-982 (2002).

2. Hadziyannis, S.J. et al. Peginterferon-alpha2a and ribavirin combination therapy in chronic hepatitis $\mathrm{C}:$ a randomized study of treatment duration and ribavirin dose. Ann. Intern. Med. 140, 346-355 (2004).

3. Talal, A.H. et al. Pharmacodynamics of PEG-IFN alpha differentiate HIV/HCV coinfected sustained virological responders from nonresponders. Hepatology $\mathbf{4 3}$ 943-953 (2006).

4. Harris, J.M. \& Chess, R.B. Effect of PEGylation on pharmaceuticals. Nat. Rev. Drug Discov. 2, 214-221 (2003).

5. Greenwald, R.B., Choe, Y.H., McGuire, J. \& Conover, C.D. Effective drug delivery by PEGylated drug conjugates. Adv. Drug Deliv. Rev. 55, 217-250 (2003).

6. Veronese, F.M. \& Pasut, G. PEGylation, successful approach to drug delivery. Drug Discov. Today 10, 1451-1458 (2005).

7. Grace, M.J. et al. Site of PEGylation and polyethylene glycol molecule size attenuate interferon-alpha antiviral and antiproliferative activities through the JAK/STAT signaling pathway. J. Biol. Chem. 280, 6327-6336 (2005).

8. Dhalluin, C. et al. Structural and biophysical characterization of the $40 \mathrm{kDa}$ PEG-interferon-alpha2a and its individual positional isomers. Bioconjug. Chem. 16, 504-517 (2005).

9. Pavlou, A.K. \& Reichert, J.M. Recombinant protein therapeutics-success rates, market trends and values to 2010. Nat. Biotechnol. 22, 1513-1519 (2004).
10. Yamamoto, Y. et al. Site-specific PEGylation of a lysine-deficient TNF-alpha with full bioactivity. Nat. Biotechnol. 21, 546-552 (2003).

11. Gentle, I.E., De Souza, D.P. \& Baca, M. Direct production of proteins with $\mathrm{N}$-terminal cysteine for site-specific conjugation. Bioconjug. Chem. 15, 658-663 (2004).

12. Sato, H. Enzymatic procedure for site-specific PEGylation of proteins. Adv. Drug Deliv. Rev. 54, 487-504 (2002)

13. Kinstler, 0., Molineux, G., Treuheit, M., Ladd, D. \& Gegg, C. Mono-N-terminal poly(ethylene glycol)-protein conjugates. Adv. Drug Deliv. Rev. 54, 477-485 (2002).

14. Rosendahl, M.S. et al. A long-acting, highly potent interferon alpha-2 conjugate created using site-specific PEGylation. Bioconjug. Chem. 16, 200-207 (2005).

15. Peterson, M., Jonson, P. \& Peterson, S. Amino acid neighbours and detailed conformational analysis of cysteines in proteins. Protein Eng. 12, 535-548 (1999).

16. Leung, H.J., Xu, G., Narayan, M. \& Scheraga, H.A. Impact of an easily reducible disulfide bond on the oxidative folding rate of multi-disulfide-containing proteins. J. Pept. Res. 65, 47-54 (2005).

17. Rosendahl, M.S. et al. A long-acting, highly potent interferon alpha-2 conjugate created using site-specific PEGylation. Bioconjug. Chem. 16, 200-207 (2005).

18. Arakawa, T., Prestrelski, S.J., Narhi, L.O., Boone, T.C. \& Kenney, W.C. Cysteine 17 of recombinant human granulocyte-colony stimulating factor is partially solventexposed. J. Protein Chem. 12, 525-531 (1993).

19. Bhattacharyya, R., Pal, D. \& Chakrabarti, P. Disulfide bonds, their stereospecific environment and conservation in protein structures. Protein Eng. Des. Sel. 17, 795-808 (2004).

20. Thornton, J.M. Disulphide bridges in globular proteins. J. Mol. Biol. 151, 261-287 (1981).

21. Godwin, A. et al. Molecular dynamics simulations of proteins with chemically modified disulfide bonds. Theor. Chem. doi:10.1007/s00214-006-0134-0 (2006).

22. Shaunak, S. et al. Site-specific PEGylation of native disulfide bonds in therapeutic proteins. Nat. Chem. Biol. 2, 312-313 (2006). 
PROTOCOL

23. Balan, S. et al. Site-specific PEGylation of protein disulfide bonds using a three-carbon bridge. Bioconj. Chem. doi:10.1021/6c0601471 (2006).

24. Chapman, A.P. PEGylated antibodies and antibody fragments for improved therapy: a review. Adv. Drug Deliv. Rev. 54, 531-545 (2002).

25. Dombkowski, A.A. Disulfide by design: a computational method for the rational design of disulfide bonds in proteins. Bioinformatics 19, 1852-1853 (2003).

26. Fraczkiewicz, R. \& Braun, W. Exact and efficient analytical calculation of the accessible surface areas and their gradients for macromolecules. J. Comp. Chem. 19, 319 (1998).

27. Koradi, R., Billeter, M. \& Wuthrich, K. Molmol: a program for display and analysis of macromolecular structures. J. Mol. Graph. 14, 51-32 (1996).

28. Zloh, M., Balan, S., Shaunak, S. \& Brocchini, S. The effect of hydrogen bonding interactions on the reactivity of a novel disulfide-specific PEGylation reagent. 8th
International Conference on Fundamental and Applied Aspects of Physical Chemistry (Belgrade, Serbia, 2006).

29. Zloh, M., Balan, S., Shaunak, S. \& Brocchini, S. Modeling study of disulfide bridged PEGylated proteins. 6th European Conference on Computational Chemistry (Slovakia, 2006).

30. Smith, P.K. et al. Measurement of protein using bicinchoninic acid. Anal. Biochem. 150, 76-85 (1985).

31. Fahey, E., Chaudhun, J. \& Binding, P. Refolding of low molecular weight urokinase plasminogen activator by dilution and size exclusion chromatography. A comparative study. Sep. Sci. Technol. 35, 1743-1760 (2000).

32. Arakawa, T. \& Tsumoto, K. The effects of arginine on refolding of aggregated proteins: not facilitate refolding, but suppress aggregation. Biochem. Biophys. Res. Commun. 304, 148-152 (2003). 